\title{
English for Mathematics and Science: current Malaysian language-in-education policies and practices
}

\begin{abstract}
Bahasa Malaysia (the Malay language) was chosen as the national language to unite the linguistically diverse groups in Malaysia in the mid-1950s. This choice brought about a total change in education policy, whereby Bahasa Malaysia became the medium of instruction for all subjects (other than English) in public schools. The decision saw a complete reversal of the role of English, which before the implementation of the 1963 National Language Act was the medium of instruction and administration. The current milestone in policy change is the decision to make English the medium of instruction in mathematics and science. With this change, a number of corollaries emerged that may determine the direction of policy execution. This paper examines contentious reactions to this new policy from various interest groups, teacher trainers and classroom practitioners, and to the implementation of language education programmes related to the teaching of mathematics and science. Among the issues discussed are the perceived difficulty of mastering English, the advantaged and disadvantaged bilingual learner, the rural-urban dichotomy in learner capability, and the question of national identity. (C) 2006 S.H. Chan \& H. Tan.
\end{abstract}

Keyword: Bahasa Malaysia; English for the teaching of mathematics and science (ETeMS); Language-in-education; Policy; Sociopolitical issues; Trainee practitioners 